Article

\title{
The Role of Social Media in Generation Y Travel Decision-Making Process (Case Study in Poland)
}

\author{
Agnieszka Werenowska ${ }^{1, *(1)}$ and Maciej Rzepka ${ }^{2}$ \\ 1 Management Institute, Warsaw University of Life Sciences (WULS), Nowoursynowska 166 St., \\ 02-787 Warsaw, Poland \\ 2 LOT Team sp. Z o.o, 17 Stycznia 43 St, 02-146 Warszawa, Poland; astrolabium22@gmail.com \\ * Correspondence: agnieszka_werenowska@sggw.pl; Tel.: +48-664-198-540
}

Received: 6 July 2020; Accepted: 10 August 2020; Published: 15 August 2020

\begin{abstract}
Technological development at the turn of the 20th and 21st centuries determined the possibilities of communication. Internet access has resulted in the rapid development of social media, bringing together users from around the world. Social media affect all aspects of human life, including leisure and tourism. The article focuses on the element of this influence, namely the selection of tourist destinations made by Generation Y. It presents the influence of social media on consumer choices in tourism and the specificity of tourist products. The main purpose of the study was to indicate the most commonly used social media in the process of selecting a tourist destination and implementing the journey by Generation Y. The analysis of research results shows the important place of social media in the life of Generation Y. They mostly trust materials shared in social media, although they are aware of it coloring reality, and sharing impressions from tourist destinations is per se the purpose of the trip. Facebook, YouTube, and Instagram are the most used social media for Generation Y. It was also important to define the purpose of activity in social media (SM). Studies have shown the emergence of goals not yet declared among young SM users. One of the main goals of a trip is to report and share travel content in social media. The survey method and the analysis of the literature and available reports were used. A diagnostic survey was conducted among Polish SM users, who are considered representatives of Generation Y. The survey was conducted using the CAWI (Computer-Assisted Web Interviews) method. The subject requires further empirical research.
\end{abstract}

Keywords: social media; Generation Y; Internet; tourist destinations; communication; Polish social media users

\section{Introduction}

Technological development at the turn of the 20th and 21st centuries opened up new opportunities for communication. It was quickly discovered that the largest invention—the Internet —provides extraordinary socialization opportunities, which resulted in the rapid development of social media), bringing together users from all over the globe. The Internet has transformed into a new sphere of life in which many people try to create themselves again [1].

Social networks are becoming more and more present in our daily lives. According to the Global Web Index, digital consumers spend an average of $2 \mathrm{~h}$ per day on social media and messengers [2].

Social media affect all aspects of human life, including leisure and tourism. In 2019, Facebook had over 18 million users in Poland [3] and over 2.5 billion [4] worldwide, which proves the scale of this phenomenon. Data from the report indicate that 2.9 billion people use at least one of the company's core products (Facebook, WhatsApp, Instagram, or Messenger) each month [4]. Users are often unaware of the great impact they have on their decisions. It is all the more important to examine this impact on issues related to tourism and leisure. The article focuses on an element of this influence, 
namely the choice of tourist destination by Generation Y (Generation Y, also known as the Millennium generation, is the demographic group that is the successor of Generation X) [5]. In the first part of the article, an analysis of the literature on the subject was made, screening the typology of generations. The features characterizing particular generations were discussed. The importance of social media in searching for information in the process of making decisions on the choice of a tourist destination was also shown. The second part of the article presents the results of surveys. They concerned determining the popularity of social media (SM) among the representatives of Generation Y, indicating how they use SM for obtaining information on the choice of a tourist destination, factors influencing the assessment of the attractiveness of destinations in SM, and reasons for sharing content in SM.

Young people belong to the most active demographic groups in Poland in relation to tourism. This is due to many reasons, including primarily the lack or limited professional and family obligations [6]. The purpose of the article was to indicate the most used social medium in the process of choosing a tourist destination and fulfilling the journey by Generation Y. It was assumed that the most popular social medium for obtaining information on travel destinations in the studied group is Facebook, and the attractiveness of a given destination is assessed on the basis of an opinion in social media. The hypothesis regarding the purpose of the travel was also verified.

Nowadays, the use of devices such as computers, smartphones, and tablets has become commonplace. The generation born after 1980 cannot imagine a world without technical innovations. Social media have become an indicator of their existence. You can risk saying that a person who does not have a Facebook account "does not exist" and is even excluded from social circles. Social media are not limited to the most popular ones such as Facebook or Twitter. They discuss various topics and serve as places for exchanging experiences, opinions about products and services, transferring information from everyday life, holidays, or successes. In many cases, they influence the formation of opinions in the process of making purchasing decisions. For example, those include reviews and opinions posted in social media that affect whether we buy airline tickets to a given destination or go on vacation to the same place as our friends publishing holiday photos. Inspiration can also come from a movie watched on YouTube showing a journey to interesting corners of the world that will contribute to buying airline tickets and going to the presented place. In the article, special attention is paid to the behavior concerning decision making in the tourism industry among representatives of the generation that is characterized by high attachment to social media, namely Generation $\mathrm{Y}$, the so-called Millenials. Despite many social media studies on purchasing decisions in many industries, there is still a need to deepen the knowledge on Generation Y consumer behavior in the tourism industry.

Among others Xiang, Magnini, Fesenmaier (2015) [7], or Dębski, Krawczyk, Dworak (2019) [8] write about the essence of carrying out research in the discussed area. For leisure organizers, tourist offices, etc., it is extremely important to follow the client's needs and the preferred form of communication. In the conducted study, attention was drawn to the need of Generation $Y$ to document almost every aspect of life on the Internet. In subsequent stages of the research, it would be worth defining in detail exact reasons for uploading photos or a video report from a trip to Facebook. Perhaps it is becoming an element of increasing "prestige". Particularly important, not mentioned in previous analyses, is the emerging of the aim of publishing one's trips on social media: sharing impressions from tourist destinations as a goal in itself.

\section{Literature Review}

\subsection{Generation Typology}

The Internet has become a source of interpersonal contacts, especially among young users. It revolutionized interpersonal relations, significantly influencing their quality and intensity [9]. In times of dynamic dissemination of information technologies, we are dealing with the so-called digital natives. They often treat real and virtual space as one and identical. This division is to emphasize the way the Internet is used but does not refer to proficiency in using this medium. The conventional 
division date is the 1980s. Persons born in this period and later are "digital natives", and those born before this period are "digital immigrants" [10]. Digital immigrants also appear in other studies, among others, Behary (2013) and Ktoridou, Eteokleous (2011). Other authors who also wrote about this phenomenon include Loos (2012) and Marchant, O'Donohoe (2014). However, others have researched digital natives: Cantoni, Rapetti (2015); Joiner et al. (2013); Kir wan, Mc Guckin (2014); Kivunja (2014); Mäntymäki, Riemer (2014); Mitan (2014); Reid, Van Niekerk (2014). For Generation Y, the term "wired generation" also appears in the literature because of the ability to use online tools. They are confronted with the challenge for the information society, which is the dissemination of Web 2.0 websites. [11]. The literature on the subject has several classifications of generation groups. One of the possible classifications was proposed by Lyons, Schweitzer, and Eddy [12] (pp. 8-21):

- the Silent Generation-born in 1922-1944,

- Baby Boomers-born in 1945-1964,

- Generation X-born in 1965-1980,

- Generation Y (the so-called millennials) - born in 1981-1994,

- Generation Z-born after 1995. It also often appears under the name C, meaning "connect, communicate, change".

- The following generations are most often distinguished [13,14]:

- Veterans (Radio Babies, The Silent Generations) - born in 1930-1945,

- Baby Boomers-born in 1946-1969,

- Generations X (Baby Busters)-born in 1970-1979,

- Generation Y (Millennials)—born after 1980.

\subsection{Generation $Y$ Characteristics}

Those in Generation Y are also called "Millennials", meaning those born in 1980-2000 [15] are described as lazy, selfish, and having unrealistic expectations in relation to work. They are confident and convinced of their own greatness. Their undoubtedly distinctive feature is openness to change and a greater level of optimism in relation to earlier generations. They have the ability to search for information that is directly related to knowledge of new technologies. They also use it to create communities, often communicating with each other. They can perform many tasks at the same time (90\% of respondents aged 18-24 believe that listening to an iPod during work increases their efficiency; young people need stimuli in an almost continuous way, e.g., in the form of music that stimulates them at work) [16]. This generation is almost always online. They are active in social media, shop online, and look for information, entertainment, and social relationships online. Polish Millennials can be divided into 2 groups, namely those born between 1980 and 1989 and those born between 1990 and 2000 [Table 1]. The interest in this group is so great because of its huge social and economic potential. The first group had an opportunity to experience the times without the Internet. Together with the younger part, they are a significant group whose purchasing power is constantly increasing. According to the Central Statistical Office, 38,386 million women and men live in Poland [17], of which $28.83 \%$ are representatives of Generation $\mathrm{Y}$.

Table 1. The generation defined.

\begin{tabular}{ccc}
\hline Name of the Generation & Range of Years & Age \\
\hline Silents & $1928-1945$ & $75-92$ \\
Boomers & $1946-1964$ & $56-74$ \\
Generation X & $1965-1980$ & $40-55$ \\
Millennials/Y & $1981-1996$ & $24-39$ \\
Generation Z & $1997-2012$ & $8-22$ \\
\hline
\end{tabular}

Source: https://www.pewresearch.org/fact-tank/2019/01/17/where-millennials-end-and-generation-z-begins/. 
Millennials certainly have a significant impact on the development of the entire country and all branches of the economy, including tourism.

Generation $\mathrm{Y}$ is a decidedly larger part of the population between the age of 19 and 39, and at this point, their behavior is the compass that entrepreneurs must follow if they want to develop and attract their attention.

\subsection{Defining the Concept of a Tourist Destination}

The concept of a destination is relatively new in the literature. Earlier, it appeared in tourist offers. Is a neologism, translating "tourist destination" from English. It has a geographical dimension and is understood as geographical space [18]. Nowadays, this formulation can be found in many scientific publications, e.g., Majewski (2007), Kruczek (2017), Zmyślony (2003), and Mikos von Rohrscheidt (2009). A tourist destination is a location that meets the unique conditions in terms of tourism and has values that distinguish it from other destinations. Visitors shape a specific image about the destination as well as certain expectations based on previous experiences, heard opinions, advertisements, newspaper articles, and popular beliefs, before visiting a given place [19].

In this study, the definition for a tourism destination was adopted from Goeldner and Ritchie as "a particular geographic region within which the visitor enjoys various types of travel experiences" [20] (p. 466).

\subsection{SM in Search for Information in the Process of Making Decision on a Tourist Destination}

Online shopping and earlier searching for information are now an inseparable element of the purchasing process. Information disseminated in new media is more visible and noticeable, and thus the effectiveness of reaching recipients increases [21]. Social media significantly support the development of the tourist services market. They have also changed its character. Among the most active tourist groups of consumers there are primarily young users of new media [22]. The use of this communication channel is used at every stage of making purchasing decisions: from shaping needs, searching for information, comparing offers, choosing destinations, to sharing opinions with other social media users [23].

Choosing a tourist destination, making a decision about buying a service, is associated with a high risk of buying a certain 'promise'. Therefore, clients aware and knowledgeable about modern technologies, in which Generation Y certainly can be included before making a decision, seek the opinions of other clients who have already used this type of service, thus reducing the risk of making a mistake. It is worth mentioning that over $95 \%$ of tourists use digital resources while traveling. During one trip, the average traveler uses over 19 websites and mobile applications [24]. Statistical data clearly indicate the huge range of social media because the total number of active users of social media in the world in 2019 was as many as 3.484 billion. This represents $45 \%$ of the total population and an increase of 280 million compared to the previous year. The largest group of people using social media was men aged $25-34(19 \%)$, constituting $1 / 5$ of all users. Men were also the second largest group-those aged 18-24. The smallest number of users was in the age group over 65 (2\% for both sexes) [25].

Since the beginning of the Web 2.0 era, social media have become increasingly important in the decision-making process of choosing a tourist destination and planning a trip [26]. The results of research conducted by BrightLocal in 2018 show that as much as $91 \%$ of the US population regularly or occasionally uses reviews, and $84 \%$ trust it as well as a personal recommendation [27]. Reviews have a dual use: they provide information about products and services and serve as recommendations [28]. They are a heuristic element of making shopping decisions, which is important regardless of the personal characteristics of the people who write such recommendations [29].

The reviews have, as confirmed by the results of the Local Consumer Review survey conducted in 2019, a huge impact on consumer behavior. Positive reviews encouraged $91 \%$ of consumers to take advantage of an offer of the rated company, and $82 \%$ of respondents were discouraged by negative 
reviews. On average, consumers read 10 reviews before making a purchasing decision. It is important that among consumers, $97 \%$ read answers to reviews, which is extremely important from the point of view of companies in the process of building credibility and trust [30]. These results indicate how the popularity and the success of tourist destinations is closely linked to their presence on the Internet [31]. Research conducted by Gupta (2019) indicates an important role of social media in meeting informational needs in the purchasing decision-making process. The author confirms that while there are negative aspects of SM, the benefits outweigh the drawbacks [32].

The greatest value of social media for tourism and tourists is the average rating of facilities and information provided by Internet users, which includes, for example, location, directions how to reach the place, cleanliness, value for money, etc. This information is divided by types of travelers, duration of the visit, and language in which they posted information [33].

Presented by Matikiti-Manyevere and M. Kruger (2019), the results of the study show that Facebook, YouTube, Instagram, and TripAdvisor are the most frequently used sites by tourists in the travel planning process. The growing popularity of Instagram was also noted. For a travel agent, it is essential to understand the behavior of tourists in online environments to create effective marketing strategies in social media [34]. The importance of Facebook and TripAdvisor is emphasized in the research by Jadhav et al. (2018) [35].

Tourism businesses can raise the cost of conversion provided that they have an effective value creation strategy and concentrate on customizing their services [36].

\section{Materials and Methods}

The methodology used included tools to identify the most used social medium in the process of selecting a tourist destination and fulfilling the journey by Generation Y.

It was significant to determine the aim of the activity in SM. Hypotheses regarding the purposefulness of trips and ways to assess the attractiveness of a given destination were also verified. The initial stage of the research procedure was the analysis of literature and source materials.

The research used the survey method. According to Apanowicz, they may relate to "the state of consciousness of a given community in terms of socio-economic activities in general and in detail. The most commonly used research technique in the diagnostic survey method is interview and questionnaire. These techniques are supplemented by document analysis and statistical methods [37] (p. 71).

The survey was carried out on 111 representatives of Generation Y, i.e., those born between 1980 and 2000. The respondents completed the online questionnaire using Google Forms at the turn of April and May 2019. Among the respondents, $72 \%$ were women and $28 \%$ were men. The respondents answered a number of issues related to their experience regarding the use of social media and the presence of a tourist element in them.

The survey questionnaire was addressed to SM users. Thanks to the fact that the first question was verifying, only people using SM and the Generation Y representatives participated in the study. They were students of Warsaw universities. The questions contained in the questionnaire were closed with a cafeteria of answers. The questions initially referred to the knowledge of SM and the information contained therein concerning places of a tourist nature. Next, they involved the assessment of the attractiveness of the tourist places described in SM, its influence on the decision of choosing a destination, experiences presented in SM, and the types of published materials, its credibility, and publication purposes.

The questionnaire for the survey was initially verified among 26 people representing the Millennium generation. The selection was made using the snowball sampling technique. These studies helped verify the questionnaire, which was then addressed to the research group. In the selection of the sample, the non-probability convenience sampling method was used. It should be mentioned that the research was exploratory. The research stages are presented in Table 2. 
Table 2. Research stages.

\begin{tabular}{ccccc}
\hline I & II & III & IV & V \\
\hline $\begin{array}{c}\text { Preparation of the survey } \\
\text { questionnaire }\end{array}$ & $\begin{array}{c}\text { Testing of the questionnaire } \\
\text { among 26 respondents }\end{array}$ & $\begin{array}{c}\text { Verification of } \\
\text { the survey questionnaire }\end{array}$ & Selection of respondents & $\begin{array}{c}\text { Conducting research } \\
\text { among 111 respondents }\end{array}$ \\
\hline & & Source: own study. & &
\end{tabular}

Therefore, it needs to be deepened and expanded in quantitative terms. Replication with various factors influencing the assessment of the attractiveness of travel destinations in SM and the reasons for sharing content in SM is needed. The research results are a valuable source of information for tourist enterprises, especially in the process of creating communication and promotional campaigns.

\section{Results}

\subsection{Popularity of SM among Representatives of Generation $Y$}

All respondents declared their presence in social media. This shows that they have an important place in the daily life of Generation Y.

The respondents mainly used Facebook (92.7\%). Twitter (80.2\%) enjoys relatively high recognition, although it is not actively used by young people. The data are presented in Figure 1.

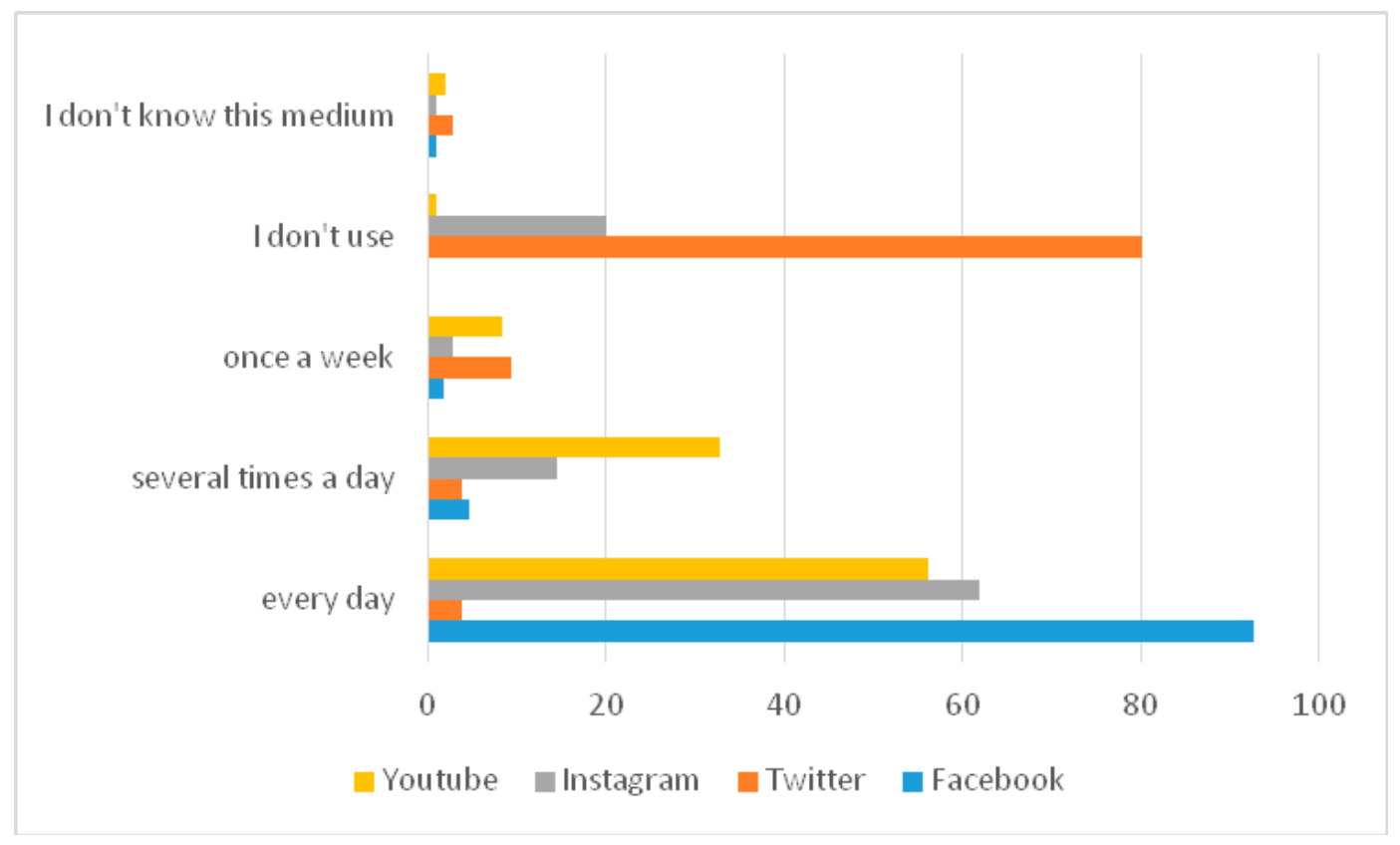

Figure 1. Frequency of use of particular social media [\%]. Source: own work.

World statistics indicate 330 million active users per month in 2019. For comparison, 2.4 billion users use Facebook monthly, of which 1.59 billion use Facebook every day [38]. In Poland, Twitter is popular mainly among politicians and journalists. The idea behind this site is based on sharing short text messages known as 'tweets', which are currently limited to 280 characters. This medium is eagerly used by politicians in Poland and around the world who use it to communicate with their electorates. Instagram was the third medium indicated by the respondents $(61.8 \%)$. It is important that, unlike Twitter, respondents use it every day. It probably has to do with the fact that it focuses on visual materials such as photos that Generation $\mathrm{Y}$ takes so willingly to depict various events from users' lives. In January 2020, 7,202,000 used Instagram in Poland, which accounted for 19\% of the total population [39]. Daily use of another medium, i.e., YouTube, was declared by $56.1 \%$, and $32.7 \%$ used YouTube several times a day. In 2019, more than 2 billion logged in users were registered who visit YouTube every month. Every day, viewers watch over a billion hours of films [40]. 
All media-Facebook, Tweeter, Instagram and YouTube-are not strictly tourist-oriented. Interesting results relate to the analysis of the literacy of the media, which are more associated with tourist services. The first was TripAdvisor, whose knowledge was declared by $47.7 \%$ of respondents, of which $34.6 \%$ used it, which may indicate relatively low popularity. The reasons for this phenomenon can be seen in a narrow topic, which is useful only when planning trips. Respondents also indicated Snapchat. It is a portal similar to Instagram but based on the idea of sending to friends photographic or film material that is displayed only once and then disappears forever. This solution was indicated by $21.5 \%$ representatives of the surveyed population who used Snapchat every day. The majority of respondents (93.6\%) came into contact with materials representing tourist places during the use of the said media. Such great interest is an expression of the popularity of the topic of travel in social media, whose users willingly share information and experiences from expeditions.

\subsection{Use of SM in Obtaining Information on Tourist Destination Selection}

In the 21st century, the tourist market is increasingly moving to the Internet. The development of information and communication technologies has influenced changes in this sector. Acquiring customers in the group of Generation Y requires adaptation to their needs, style of rest, recreation, and the use of communication channels used by this generation [41]. The surveyed representatives of Generation Y, looking for tourist destinations, use various websites where they can find information, descriptions and reviews. Analysis of the research results showed that TripAdvisor was used most frequently (55.3\%). The results are shown in Figure 2.

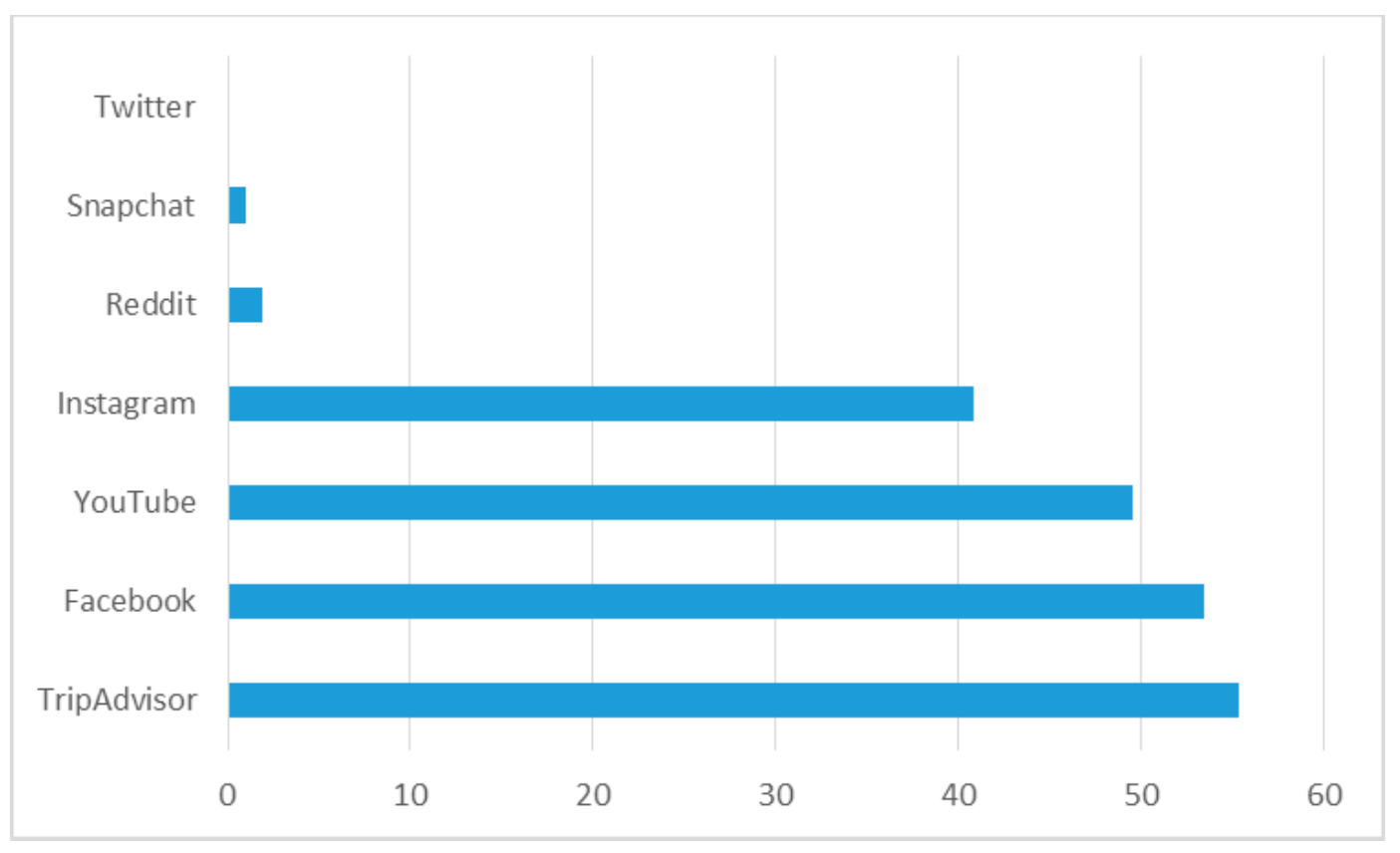

Figure 2. Media for obtaining information on tourist destinations by Generation Y [\%]. Source: own work.

It is noteworthy that half of the respondents do not use this portal on a daily basis, but when they need information about a given destination, Generation $Y$ decides to use the source associated even with the name with travel advice. Another place to look for inspiration and information on tourist destinations was Facebook (55.3\%), whose popularity is closely related to the general use of this medium, which is $100 \%$ among the respondents. Generation Y prefers quick and easy access to content that interests them. One of the indicated options was YouTube $(49.5 \%)$, whose strength lies in the film message allowing for greater immersion with the shown destination, and Instagram (40.8\%), whose advanced tools allow presenting photos in an extremely beneficial way. Twitter and Snapchat 
obtained minimal votes, indicating their unimportance in terms of impact on the Generation $Y$ choices in the area of potential destinations of travel.

\subsection{Factors Influencing the Assessment of the Attractiveness of a Tourist Destination in SM}

There are many factors that influence the evaluation of a place's attractiveness. For users of social media, tourism-related materials are important. Only $6.8 \%$ of respondents believed that social media travel content did not affect their opinion of the destinations, while the vast majority of $93.2 \%$ confirmed that their travel decisions were often inspired by information posted on social media. Pictures that may induce indecisive people to choose a specific holiday destination are also inspiring. Only for $4.9 \%$ that was the main reason for making the decision, while for $64.1 \%$, the information obtained from social media was one of the factors of choice, and therefore, they may have tipped the scales and made the place more attractive compared to other alternatives, as shown in Figure 3.

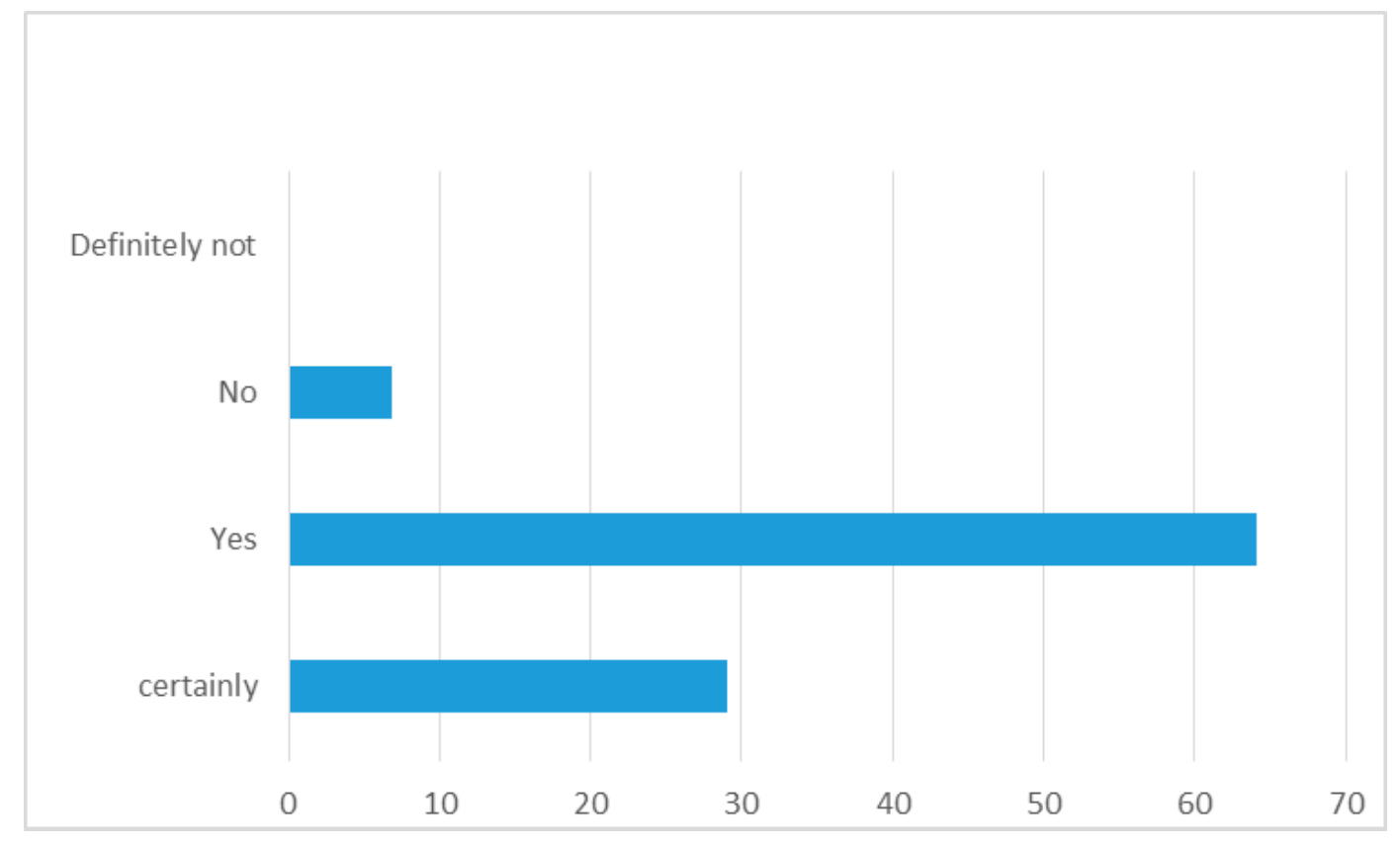

Figure 3. The influence of tourism materials in social media on Generation Y [\%]. Source: own work.

The relatively high percentage of respondents who declared no such connection is puzzling. This may be due to the fact that the older Generation $Y$ is not as dependent on the use of social media as the younger part of Generation $Y$ raised during the great technological boom at the beginning of the 21st century.

\subsection{Reasons for Sharing Content in SM}

Social media users have many reasons to share their content and read other posts. The New York Times Customer Insight Group study identified five key reasons why people decide to share something with others: entertainment, self-expression, developing and caring for relationships, a sense of satisfaction that they are doing something for others, and sharing their support for social issues [42].

When considering the impact of social media on travel destination decisions, it should be noted that most of this activity is driven by the users themselves, who take hundreds of photos during their vacation, and often, some of them are later on their social accounts, where all friends can see them. Most of the respondents added such materials (88.4\%), of which $41.8 \%$ did so regularly. It is a very active part that cannot imagine traveling without showing their holiday adventures to friends 
and followers. Only $11.7 \%$ of respondents found it embarrassing to show themselves in this way in a public forum.

Social media users who were active in uploading materials from holidays and trips declared mainly photo materials as the ones they most often publish $(96.7 \%)$. The reason for this is undoubtedly the ease with which it can be done and the weight of the moment captured in the photo. Video was chosen by only $25.3 \%$, and the reason may be definitely the greater skills required to create a good video than a photo as well as less processing options on mobile devices, as shown in Figure 4.

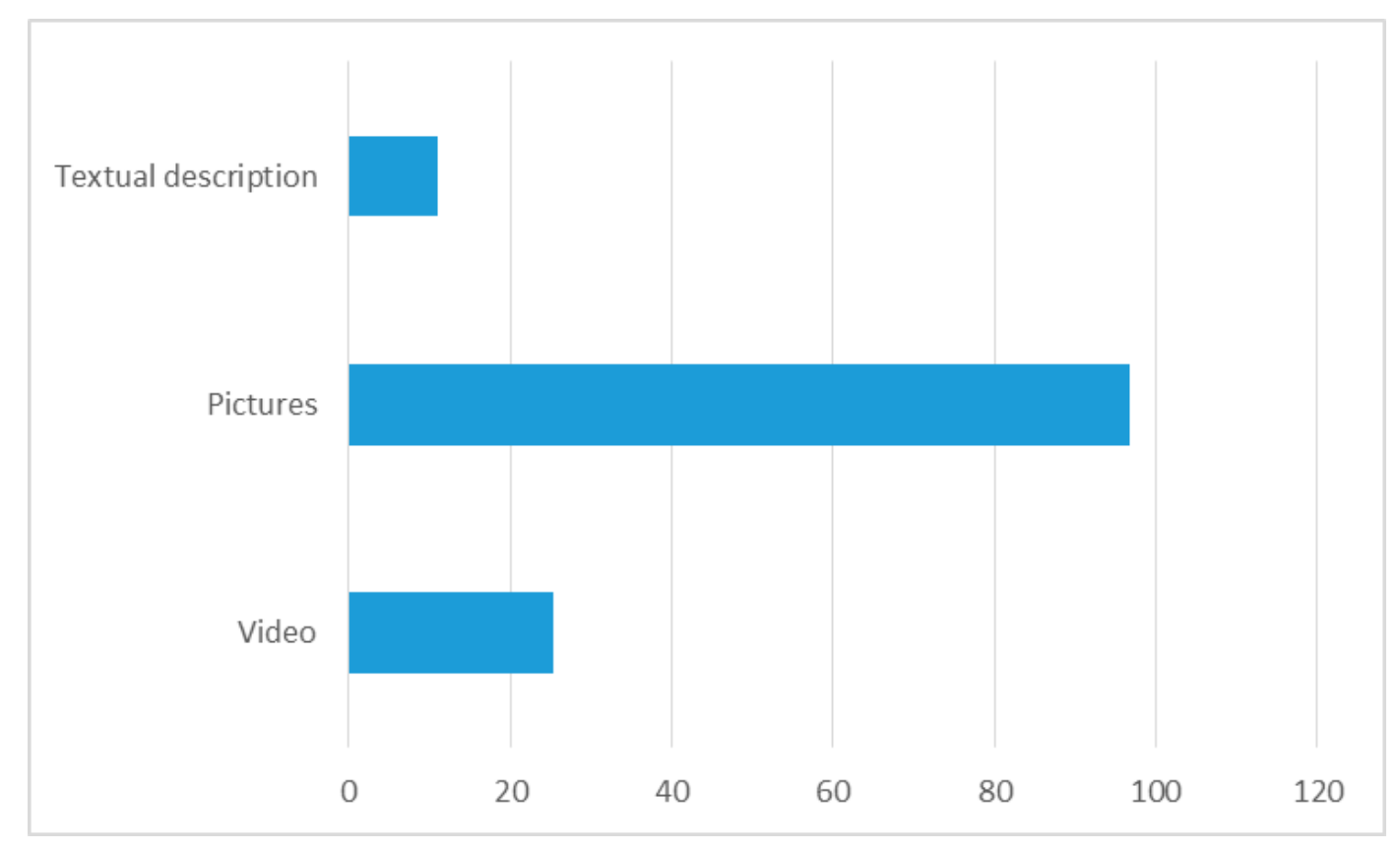

Figure 4. Type of content to be shared during the trip [\%]. Source: own work.

Text descriptions were not recognized by Generation $\mathrm{Y}$ and appeared in addition to the more popular forms mentioned above. The shots shown in the pictures do not always reflect the true picture of reality. It turns out that almost half $(46.6 \%)$ of respondents believed the images presented in social media, claiming that most of them are in line with reality. Total compliance was declared by $13.6 \%$ [ 43$]$. It is worth noting that $37.9 \%$ of respondents said that often in pursuit of recognition and the desire to show their life from the best possible side, they only commemorate the best sides of given places, avoiding showing the dark sides of tourist destinations. The data are shown in Figure 5.

Nowadays, when almost every aspect of the life of Generation $\mathrm{Y}$ is immortalized on the Internet, it is natural that for some, sharing travel materials can turn into one of the goals of the trip. Allianz Travel Insurance conducted a Vacation Confidence Index study among three generations: Millenials (18-34 years), Generation X (35-54 years), and Baby Boomers (+55 years), in which participants were asked how they engage in "social media". It turns out that Generation $Y$ is much more likely than any other age group to present their travels on social media. It is worth paying attention to the reasons for such involvement. Over half (58\%) share photos in which they look best, and $52 \%$ share photos in which their surrounding looks best. A relatively large proportion of Millenials (37\%) do this to arouse jealousy among friends and family, and $27 \%$ treat it as a way to compete with others who also share materials from their holidays at the same time [44].

The analysis of the research results showed that as many as $80.6 \%$ use social media for leisure and visiting new places; one of the highlights, among the destinations of travel, is the emergence of a new goal, which has evolved as a result of technological development, is driving the development of social media, and now occupies an important place in the criterion of selecting a tourist destination. 


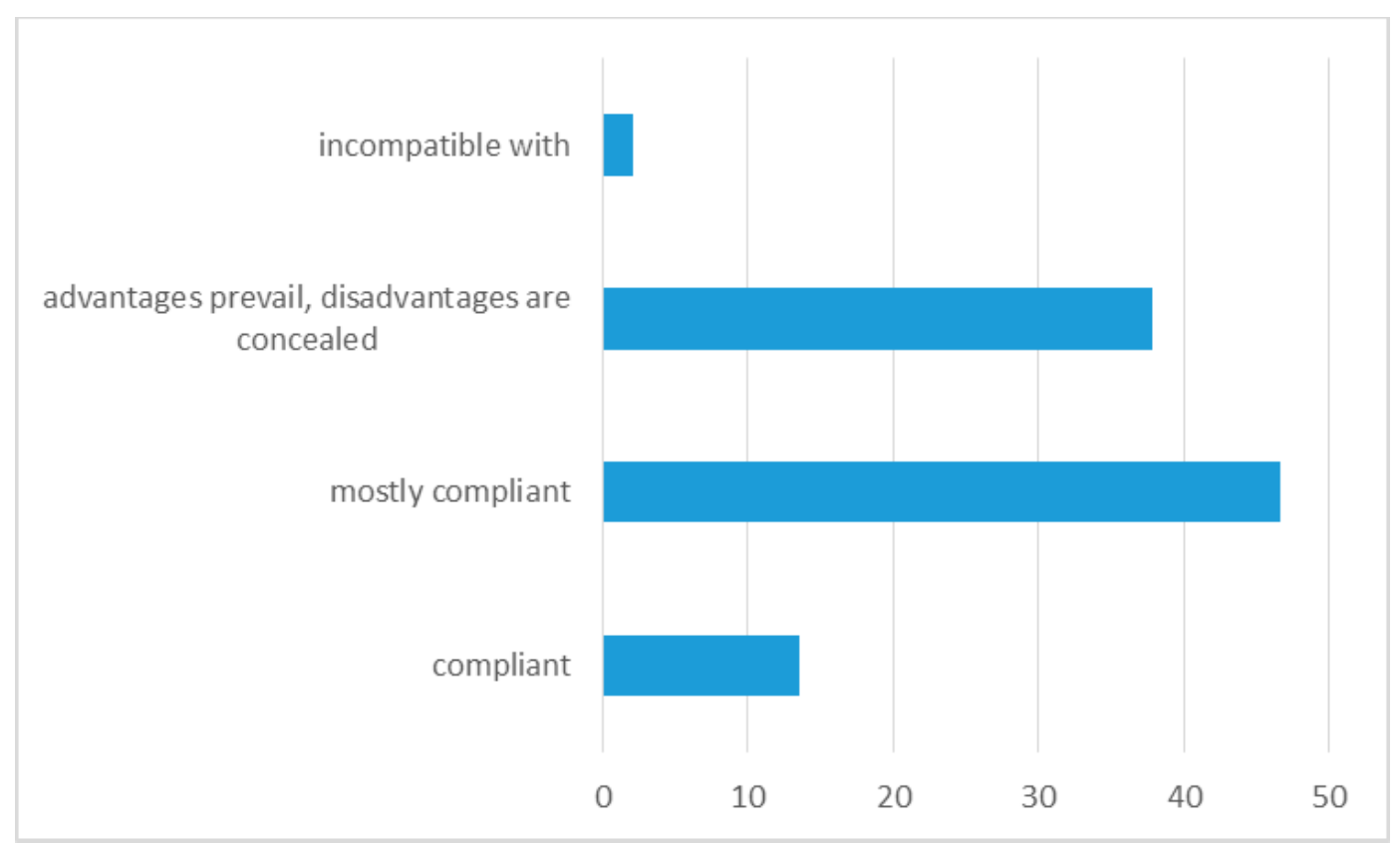

Figure 5. Conformity of the image of a tourist destination in social media with the reality [\%]. Source: own work.

\section{Discussion}

The number of publications that examine social media shows that researchers are very interested in the impact of social media on the purchasing decisions of individual generations. Issues related to the use and role of SM in the life of contemporaries are raised in many publications by a lot of scientists from around the world. It is worth mentioning here among others Hussain (2020) [45], Flachenacker (2019) [46], Mosterd and Wijers (2019) [47], Shatal et al. (2019) [48], Kumar and Namada (2019) [49], Liebowitz et al. (2018) [50], Reformat and Reformat (2018) [51], and Christou (2015) [52].

Considering the fact that Generation $\mathrm{Y}$ and $\mathrm{Z}$ are the main social media users, testing their purchasing behavior as the basis for planning communication and promotion strategies behavior in the purchasing process of Generations $Y$ and Z has been raised in many publications: Littman (2008) [53], Ratajczyk (2017) [54], Zhang et al. (2018) [55], Badowska and Delińska (2019) [56], and Maurer and Siller (2019) [57].

Tourist destinations in the modern world must evolve along with increasing technological and cultural changes. The key to successfully promoting tourist destinations is no longer spending millions of dollars on TV advertising campaigns or printing brochures. The most credible type of promotion is content created by people visiting given places and recommending them to other potential travelers by showing how they look by publishing photos and opinions.

As a result of the available reports and literature analysis, the most popular social media used by Millennials were presented with an emphasis on their advantages when it comes to tourist content. Many studies point to the role of SM in the decision-making processes of Generation Y. For example, this research problem is discussed by Pikuła-Małachowska (2018) [58] and Gołab-Andrzejak (2016) [59]. According to the ACCENTURE I FASHIONBIZNES.PL report, before making a purchase decision, Generation $\mathrm{Z}$ uses the opinions of many people. In the first place, they take into account opinions of the immediate family (65\%) and friends and verify opinions of users on the Internet (64\%) [60]. On the other hand, there was no indication of the new goal, which emerged after the analysis of the results of the conducted research and mainly related to reporting and sharing the content of travels on social media. That may be the beginning of further in-depth research aimed at e.g., determining the elements of these relationships. 
The main research problem concerned the impact of social media on consumer choices in tourism. The research determined the extent of impact that social media exert on the choice of destination by Generation Y. The following hypotheses were verified in the studies:

1. The most popular social medium for acquiring information on travel destinations is Facebook.

2. Generation $Y$ assesses the attractiveness of a given destination based on opinions in social media.

3. One of the main goals of the trip is to report and share travel content on social media.

4. Content shared on social media affects the choice of travel destination.

\section{Conclusions}

Generation $Y$ sees in social media the opportunity to submit their opinions on various topics. It is a channel for transmitting opinions on service providers and holiday experiences, sharing blogs to help other travelers [61]. Therefore, it can be expected that the role of recommendations communicated via social networking platforms may be even stronger in the future [62]. Among others, Buczek (2017) and Gogoi (2019) emphasize that in their research.

Research has shown that visual materials are very popular among Millenials. Generation Y mostly trusts material shared on social media but is aware of the deliberate coloring of reality in some cases. It turns out that sharing impressions from tourist destinations is the purpose per se. The most popular social media used to obtain information on travel destinations for Generation Y are Facebook, YouTube, and Instagram. Badowska and Delińska (2018) confirm that in their study. To sum up, based on the analysis of the results of the conducted research, the following conclusions were drawn:

- The representatives of Generation Y seek information about tourist destinations using TripAdvisor or Facebook,

- Generation Y indicates YouTube and Instagram as platforms that have quick and easy access to the content that is interesting for them,

- Information obtained from social media was one of the factors in the selection of tourist destination,

- Visual content, such as photographs, is very popular among the Millennials,

- More than half of the respondents share the photographs in which they look the most attractive,

- One of the reasons for sharing pictures from trips is to make friends and family jealous,

- Generation Y mostly trusts social media materials but is aware of the purposeful coloring of reality,

- Sharing the experience of a tourist destination is an end in itself,

- The content generated by the Millennials in social media is very effective advertisement, or anti-advertisement for a given destination,

- Facebook, YouTube, and Instagram are the most widely used social media by Generation Y.

It should be noted that the research was exploratory and requires deepening. Its results are a valuable source of information for enterprises whose target groups are representatives of Generation Y. The research needs to be expanded in quantitative terms and requires a replication approach. The survey should also be further deepened with issues related to the determinants of social media selection in the search for destinations, which could be helpful when creating information strategies through SM.

Author Contributions: Conceptualization, A.W. and M.R.; methodology, A.W. and M.R.; software, A.W. and M.R.; validation, A.W. and M.R.; formal analysis, A.W.; investigation, A.W.; resources, A.W.; data curation, A.W.; writing-original draft preparation, A.W.; writing-review and editing, A.W.; visualization, A.W.; supervision, A.W.; project administration, A.W.; funding acquisition, A.W. All authors have read and agreed to the published version of the manuscript.

Funding: This research received no external funding.

Conflicts of Interest: The authors declare no conflict of interest. 


\section{References}

1. Aboujaoude, E. The virtual personality of our time. The dark side of e-personalities. In Wirtualna Osobowość Naszych Czasów. Mroczna Strona E-Osobowości; Wydawnictwo Uniwersytetu Jagiellońskiego: Kraków, Poland, 2012.

2. Iglesias, C.A.; Patti, V. Editorial for the Special Issue on "Love \& Hate in the Time of Social Media and Social Networks". Information 2018, 9, 185. [CrossRef]

3. Social Media Users in Poland. Available online: https://napoleoncat.com/stats/social-media-users-in-poland/ 2019/12 (accessed on 25 February 2020).

4. Number of Monthly Active Facebook Users Worldwide as of 1st Quarter 2019. Available online: https: //www.statista.com/statistics/264810/number-of-monthly-active-facebook-users-worldwide/ (accessed on 25 February 2020).

5. Management Encyclopedia. Available online: https://mfiles.pl/pl/index.php/Generacja_Y (accessed on 5 May 2020).

6. Balińska, A. Agritourism as a form of recreation for students. In Link Cultural Tourism in a Digital Era: First International Conference IACuDiT, Athens; Vicky, K., Ed.; Springer International Publishing: Cham, Switzerland, 2015; pp. 313-323. [CrossRef]

7. Xiang, Z.; Magnini, V.P.; Fesenmaier, D.R. Information Technology and Consumer Behaviour in Travel and Tourism: Insights from Travel Planning Using the Internet. J. Retail. Consum. Serv. 2015, 22, $244-249$. [CrossRef]

8. Dębski, M.; Krawczyk, A.; Dworak, D. Tourist behavior patterns Generation Y representatives (Wzory zachowań turystycznych przedstawicieli Pokolenia, Y.), Studia i Prace. Kolegium Zarządzania i Finansów. Zesz. Nauk. 2019, 172, 9-21.

9. Paliszkiewicz, J. The Role of Social Media in Innovative Education. Available online: http://www.ptzp.org. pl/files/konferencje/kzz/artyk_pdf_2016/T2/t2_0914.pdf (accessed on 25 February 2020).

10. Prensky, M. Digital Natives, Digital Immigrants. In On the Horizon; MCB University Press: Bingley, UK, 2001; Volume 9.

11. Jabłońska, M.; Bilewicz, R.K. Breakthrough generation in WEB 2.0 (Pokolenie przełomu w WEB 2.0). Acta Univ. Lodz. Folia Sociol. 2016, 56, 83. [CrossRef]

12. Lyons, S.T.; Schweitzer, L.; Eddy, S.W. How have careers changed? An investigation of changing career patterns across four generations. J. Manag. Psychol. 2015, 30, 8-21. [CrossRef]

13. Borges, N.; Manuel, R.; Elam, C.; Jones, B. Differences in motives between millennial and Generation X medical students. Med. Educ. 2010, 44, 570-576. [CrossRef]

14. Juchnowicz, M. Cultural Determinants of Human Capital Management; Oficyna Wolters Kluwer Business: Kraków, Poland, 2009; p. 118.

15. Cole, G.; Smith, R.; Lucas, L. The debut of generation Y in the American workforce. J. Bus. Adm. Online $2002,1$. Available online: http://citeseerx.ist.psu.edu/viewdoc/download?doi=10.1.1.556.1213\&rep=rep1\&type=pdf (accessed on 25 February 2020).

16. Tyler, K. The Tethered Generation. HR Mag. 2007, 52, 55.

17. Statistics Poland. Available online: www.sat.gov.pl (accessed on 25 February 2020).

18. Burkart, A.J.; Medlik, S. Turism: Past, Prestent and Future; Heinemann Publishers: London, UK, 1974.

19. Baloglu, S.; Brinberg, D. Affective Images of Tourism Destinations. J. Travel Res. 1997, 35, 11-15. [CrossRef]

20. Goeldner, C.R.; Ritchie, J.R.B. Tourism: Principles, Practices, Philosophies; Willey: Hoboken, NJ, USA, 2003.

21. Jaska, E. Using new media in creating the company's image. Zeszyty Naukowe Politechniki Częstochowskiej Zarzadzanie 2018, 31, 80-90. [CrossRef]

22. Kachniewska, M. Potential of social media in the area of popularisation of tourist activity (Potencjat mediów społecznościowych w obszarze popularyzacji aktywności turystycznej). Rozprawy Naukowe Akademii Wychowania Fizycznego we Wrocławiu 2015, 50, 35-48.

23. Delińska, L. Social media as a determinant of development of tourist services. Ekon. Probl. Ustug 2018, 130, 17-25. [CrossRef]

24. Guggenheim, J.; Kremser, S.; Jhunjhunwala, P.; McCaleb, T.; Garcia-Mon, A.A.; McCabe, L. Travel Goes Mobile. 2014. Available online: www.bcgperspectives.com/content/articles/trans-portation_travel_tourism_ digital_economy_travel_goes_mobile/ (accessed on 25 February 2020). 
25. Wearesocial. Available online: https://wearesocial.com/global-digital-report-2019 (accessed on 25 February 2020).

26. Chung, Y.; Buhalis, D. Information Needs in Online Social Networks. Inf. Technol. Tour. 2008, 10, $267-281$. [CrossRef]

27. Local Consumer Revive Survey 2018. Available online: https://www.brightlocal.com/learn/local-consumerreview-survey/?SSAID=314743\&SSCID=b1k2_vez00\#q1 (accessed on 25 February 2020).

28. Park, D.H.; Lee, J.; Han, J. The effect of online consumer reviews on consumer purchasing intention: The moderating role of involvement. Int. J. Electron. Commer. 2007, 11, 125-148. [CrossRef]

29. Smith, D.; Menon, S.; Sivakumar, K. Online peer and editorial recommendations, trust, and choice in virtual markets. J. Interact. Mark. 2005, 19, 15-37. [CrossRef]

30. Local Consumer Review. Available online: https://www.brightlocal.com/research/local-consumer-reviewsurvey/ (accessed on 25 February 2020).

31. Govers, R.; Go, F.M.; Kumar, K. Promoting Tourism Destination Image. J. Travel Res. 2007, 46, 15-23. [CrossRef]

32. Gupta, V. The influencing role of social media in the consumer's hotel decision-making process. Worldw. Hosp. Tour. Themes 2019, 11, 378-391. [CrossRef]

33. Drozdowska, M.; Duda-Seifert, M. Tourist Internet portals-a reliable source of information? Turyzm 2016, 26, 7-14. [CrossRef]

34. Matikiti-Manvevery, R.; Kruger, M. The Role of Social Media Sites in Trip Planning and Destination Decision-Making Processes. Afr. J. Hosp. Tour. Leis. 2019, 8. Available online: https://www.ajhtl.com/uploads/ 7/1/6/3/7163688/article_3_vol_8_5_2019_cut.pdf (accessed on 25 February 2020).

35. Jadhav, V.; Raman, S.; Patwa, N.; Moorthy, K.; Pathrose, J. Impact of Facebook on leisure travel behavior of Singapore residents. Int. J. Tour. Cities 2018, 4, 6-20. [CrossRef]

36. Effect of Social Media in Tourism. Available online: https://www.longdom.org/open-access/effect-of-socialmedia-in-tourism-case-in-cambodia.pdf (accessed on 20 May 2020).

37. Apanowicz, J. General Methodology; Wyd. Bernardinum: Pelplin, Poland, 2002; p. 71.

38. Whysosocial. Available online: https://www.whysosocial.pl/uzytkownicy-social-media-w-polsce-i-naswiecie/2019 (accessed on 25 February 2020).

39. Instagram Users in Poland. Available online: https://napoleoncat.com/stats/instagram-users-in-poland/2020/ 01 (accessed on 25 February 2020).

40. Youtube. Available online: https:/www.youtube.com/intl/pl/about/press/ (accessed on 25 February 2020).

41. Werenowska, A. The use of tourist mobile applications by the Y generation. Bus. Inform. 2018, 2, 86-92. [CrossRef]

42. Bostonwebdesigners. Available online: https://www.bostonwebdesigners.net/wp-content/uploads/POS_ PUBLIC0819-1.pdf (accessed on 25 February 2020).

43. Gackowski, T.; Brylska, K.; Patera, M. The Use of Social Media as a Social Practice of Different Media Generations; Wyd. Labolatorium Medioznawcze UW: Warszawa, Poland, 2018; p. 144.

44. Millenials. Available online: https://socialpress.pl/2018/07/millenialsi-publikuja-zdjecia-z-wakacji-abywzbudzic-zazdrosc-u-innych-uzytkownikow (accessed on 25 February 2020).

45. Hussain, W. Role of Social Media in COVID-19 Pandemic. Int. J. Front. Sci. 2020, 4. [CrossRef]

46. Flachenäcker, R. Social-Media-Marketing-Kunden gewinnen über XING, Facebook \& Co. In Mehr Kunden für Kleinunternehmen und Solopreneure; Springer Gabler: Wiesbaden, Germany, 2019.

47. Mostered, P. LinkedIn or Facebook. In Managing Authentic Relationships Facing New Challenges in a Changing Context; Wijers, J.P., Ed.; Institute of Strategic Relationship Management (ISRM): The Hague, The Netherlands, 2019.

48. Shatal, T.V.; Dmytriyev, G.B. SMM as Modern Marketing Technologies. Bus. Inf. 2019, 12, 446-452. [CrossRef]

49. Kumar, V.; Nanda, P. Social Media to Social Media Analytics: Ethical Challenges. Int. J. Technoeth. 2019, 10, 57-70. [CrossRef]

50. Liebowitz, J.; Paliszkiewicz, J.; Gołuchowski, J. Intuition, Trust, and Analytics, Data Analytics Applications; Taylor \& Francis Group: Milton Park, UK, 2018.

51. Reformat, B.; Reformat, P. Wykorzystanie narzędzi mediów społecznościowych w kształtowaniu wizerunku firm turystycznych. Prace Naukowe Uniwersytetu Ekonomicznego w Katowicach 2018, Kierunki rozwoju innowacji $w$ turystyce, 60-75. 
52. Christou, E. Branding Social Media in the Travel Industry. Procedia-Soc. Behav. Sci. 2015, 175, 607-614. [CrossRef]

53. Littman, S. Welcome to the new Millennials. Response Mag. 2008, 16, 74-80.

54. Ratajczyk, M. How Generation Y buys? [Jak kupuje Generacja Y?]. Studia Ekon. Zeszyty Naukowe Uniw. Ekon. Katowicach 2017, 330, 184-193.

55. Badowska, S.; Delińska, L. Smartphone as a tool to support the process of information absorption during shopping-results of research among consumers of generation Y [Smartfon jako narzędzie wsparcia procesu absorpcji informacji podczas zakupów-wyniki badań wśród konsumentów pokolenia Y]. Annales Universitatis Mariae Curie-Skłodowska Lublin-Polonia 2019, 2, 7-16.

56. Zhang, L.; Chen, L.; Wu, Z.; Zhang, S.; Song, H. Investigating Young Consumers' Purchasing Intention of Green Housing in China. Sustainability 2018, 10, 1044. [CrossRef]

57. Pikuła-Małachowska, M. The role of the Internet in making purchasing decisions by young adults (Rola Internetu w podejmowaniu decyzji zakupowych przez młodych dorosłych). Marketing i Zarzadzanie 2018, 2, 157-164. [CrossRef]

58. Gołąb-Andrzejak, E. Consumers of generation $\mathrm{Y}-\mathrm{A}$ new challenge for marketing communication (Konsumenci pokolenia Y-nowe wyzwanie dla komunikacji marketingowej). Handel Wewnętrzny 2016, 2, 140-151.

59. Accenture. Available online: https://www.accenture.com/_acnmedia/PDF-98/Accenture-raport-2019.pdf (accessed on 25 February 2020).

60. Maurer, C.; Siller, H. Iscontur Tourism Research Perspectives. Proceedings of the International Student Conference in Tourism Research; Herstellung und Verlag: Demand, Nordersted, 2019.

61. Ghandour, R.; Bakalova, R. Social media influence on the holiday decision-making process in the UK. J. Organ. Stud. Innov. 2014, 1, 45-54.

62. Kuczamer-Kłopotowska, S. The role of social media in the communication of generation Y. Handel Wewnętrzny 2016, 3, 216-227.

(C) 2020 by the authors. Licensee MDPI, Basel, Switzerland. This article is an open access article distributed under the terms and conditions of the Creative Commons Attribution (CC BY) license (http://creativecommons.org/licenses/by/4.0/). 